\title{
Rozmieszczenie Ophioglossum vulgatum (Ophioglossaceae) w Polsce oraz jego nowe stanowiska
}

\author{
Agata Stadnicka-Futoma i MaŁgorzata Jaźwa
}

\begin{abstract}
Stadnicka-Futoma, A. And JAźwA, M. 2020. Distribution of Ophioglossum vulgatum (Ophioglossaceae) in Poland and its new localities. Fragmenta Floristica et Geobotanica Polonica 27(2): 547-565. Kraków. e-ISSN 2449-8890, ISSN 1640-629X.

Abstract: The paper describes the distribution of Ophioglossum vulgatum in Poland, including localities recorded after 2000, and gives three new $O$. vulgatum sites in south-eastern Poland. Two of them are located in the Low Beskids in Bednarka and Żydowskie, and the third in the Zamojska Valley in Klemensów.
\end{abstract}

KEY WORDS: distribution, new data, Ophioglossum vulgatum, perennial, vascular plants

A. Stadnicka-Futoma (autor korespondencyjny), Zaktad Gleboznawstwa, Chemii Środowiska i Hydrologii, Kolegium Nauk Przyrodniczych, Uniwersytet Rzeszowski, ul. Zelwerowicza 4, 35-001 Rzeszów, Polska; e-mail: astadnicka@ur.edu.pl

M. Jaźwa, Instytut Biologii, Wydział Przyrodniczo-Techniczny, Uniwersytet Opolski, ul. Oleska 22, 45-052 Opole, Polska; e-mail: malgorzata.jazwa@uni.opole.pl

\section{WSTĘP}

Ophioglossum vulgatum L. (nasięźrzał pospolity) jest niewielkich rozmiarów byliną. Posiada kłącze, z którego co roku wyrasta liść podzielony na część płonną i płodną z kłosem zarodnionośnym (TlaŁKa \& Rostański 2012) (Ryc. 1). Należy do rodziny nasięźrzałowatych Ophioglossaceae, która do niedawna mieściła się w klasie paproci Polypodiopsida. Obecnie, z uwagi na cechy morfologiczne oraz dane molekularne zaliczono ją do klasy psylotowych Psilotopsida (SMITH i in. 2006).

Ophioglossum vulgatum jest gatunkiem charakterystycznym dla łąk ze związku Molinion caeruleae (MATUSZKIEWICZ 2006), niemniej ma dość szerokie spektrum siedliskowe i spotykany jest również w wielu innych, np. w zespole turzycy błotnej Caricetum acutiformis czy szuwarze mozgi trzcinowatej Phalaridetum arundinaceae (CZARNECKA 2003), a nawet w płacie żyznej buczyny na starych zrobach pogórniczych (PoDGóRSKA 2014).

W Polsce występuje na terenie całego kraju, z wyjątkiem wyższych położeń górskich (ZAJĄC \& ZAJĄC 2001) i reprezentuje cyrkumborealny element geograficzny (ZAJĄC \& ZAJĄC 2009). Nasięźrzał pospolity uznawany jest za rzadki gatunek, objęty ścisłą ochroną gatunkową (ROZPORZĄDZENIE 2014), który został wpisany na „czerwoną listę” z kategorią VU - narażony (KAŹMIERCZAKOWA i in. 2016). 


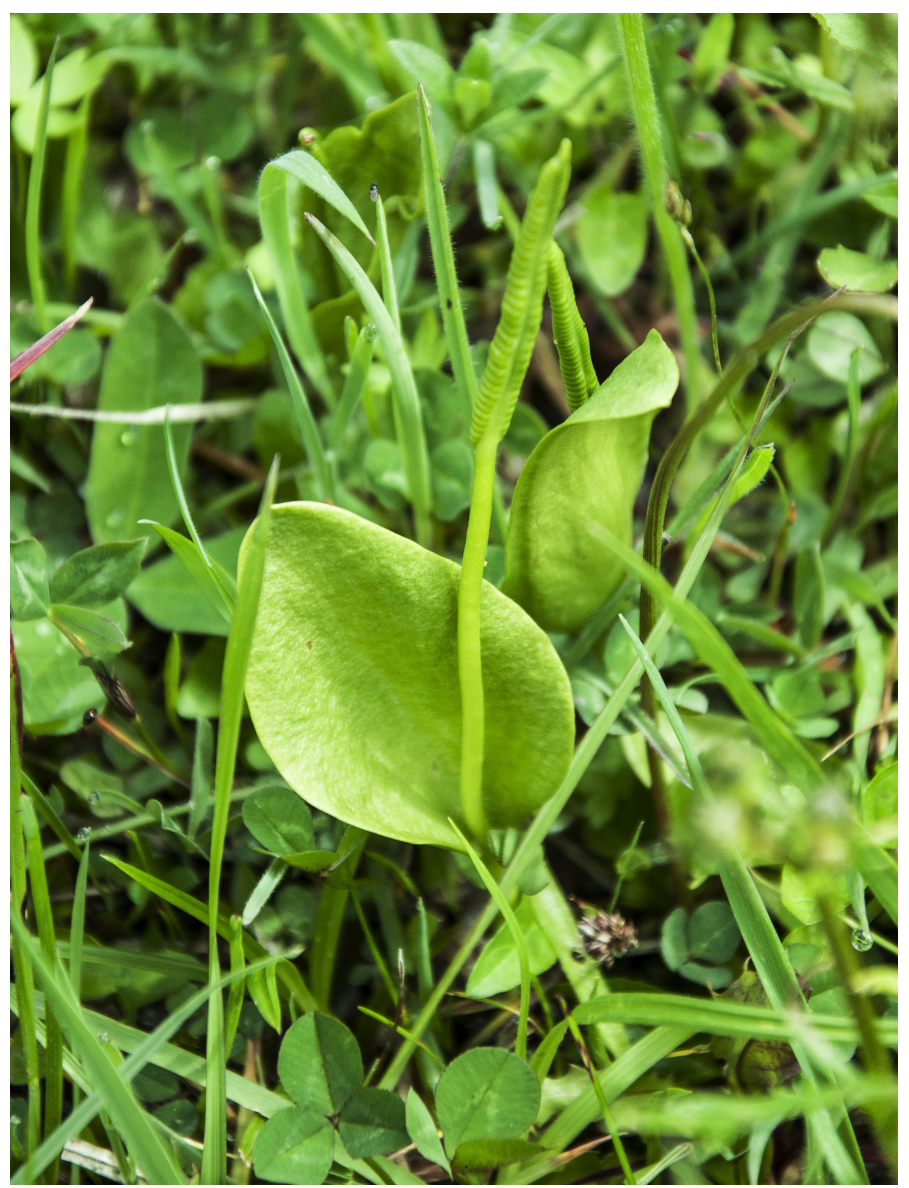

Ryc. 1. Ophioglossum vulgatum na stanowisku w Bednarce (kwadrat EG1904 oznaczony jako $\star$ ) (fot. A. StadnickaFutoma)

Fig. 1. Ophioglossum vulgatum at the locality in Bednarka (square EG1904 marked as $\star$ ) (photo by A. Stadnicka-Futoma)

Niniejsze opracowanie ma na celu przedstawienie trzech nowych stanowisk Ophioglossum vulgatum, które znaleziono podczas prowadzonych inwentaryzacji terenowych albo wycieczek. Dodatkowo celem pracy było uaktualnienie informacji o rozmieszczeniu gatunku zawartych w opracowaniu ZAJĄCA i ZAJĄC (2001), włącznie z mapą rozmieszczenia $\mathrm{z}$ uwzględnieniem stanowisk opublikowanych po $2000 \mathrm{r}$.

\section{METODyKA}

Nowe stanowiska Ophioglossum vulgatum znaleziono w 2019 r. Dodatkowo przeanalizowano dane z literatury oraz komputerową bazę danych RAR (Regionalny Atlas Roślin, udostępnioną w 2013 r.). Stanowiska gatunku stwierdzone po $2000 \mathrm{r}$. naniesiono na mapę rozmieszczenia $O$. vulgatum w Polsce (ZAJĄC \& ZAJĄC 2001), przyjmując odrębne oznaczenia. Za stanowisko przyjęto kwadrat ATPOL $10 \times 10 \mathrm{~km}$. W przypadku, gdy stanowisko podane było jako miejscowość, przyporządkowania do właściwego kwadratu siatki 
ATPOL dokonywano przy pomocy nakladki.kml (www.bdpn.pl) oraz aplikacji Google Earth. Stanowisk, dla których przyporządkowanie było niemożliwe nie brano pod uwagę, np. kiedy miejscowość mieściła się w dwóch kwadratach, a lokalizacja siedliska nie była dokładnie sprecyzowana, jak w przypadku pracy NowAK i in. (2002) - Nowa Wieś Królewska znajduje się w obrębie kwadratów CE95 i CF05. Sytuacje takie stanowiły jednak znikomy procent. W pracy zamieszczono również tabelę z krótką charakterystyką stanowisk z literatury i niepublikowanych (Tab. 1), które zostały ułożone według nazw kwadratów ATPOL.

\section{NOWE STANOWISKA}

Nowo znalezione stanowiska Ophioglossum vulgatum znajdują się w południowo-wschodniej Polsce. Dwa z nich leżą na terenie Beskidu Niskiego w miejscowościach: Bednarka i Żydowskie, natomiast trzecie mieści się w obrębie Kotliny Zamojskiej w miejscowości Klemensów (Ryc. 2).

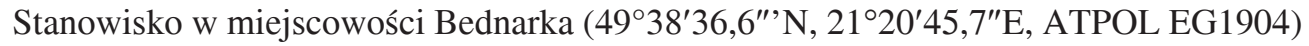
położone jest na wysokości $355 \mathrm{~m}$ n.p.m., na stoku o nachyleniu $10^{\circ} \mathrm{i}$ wystawie południowej. Ophioglossum vulgatum rósł tam w obrębie wypasanej łąki świeżej, gdzie dominowały Avenula pubescens oraz Trifolium repens. Ponadto występowały: Alchemilla sp.,

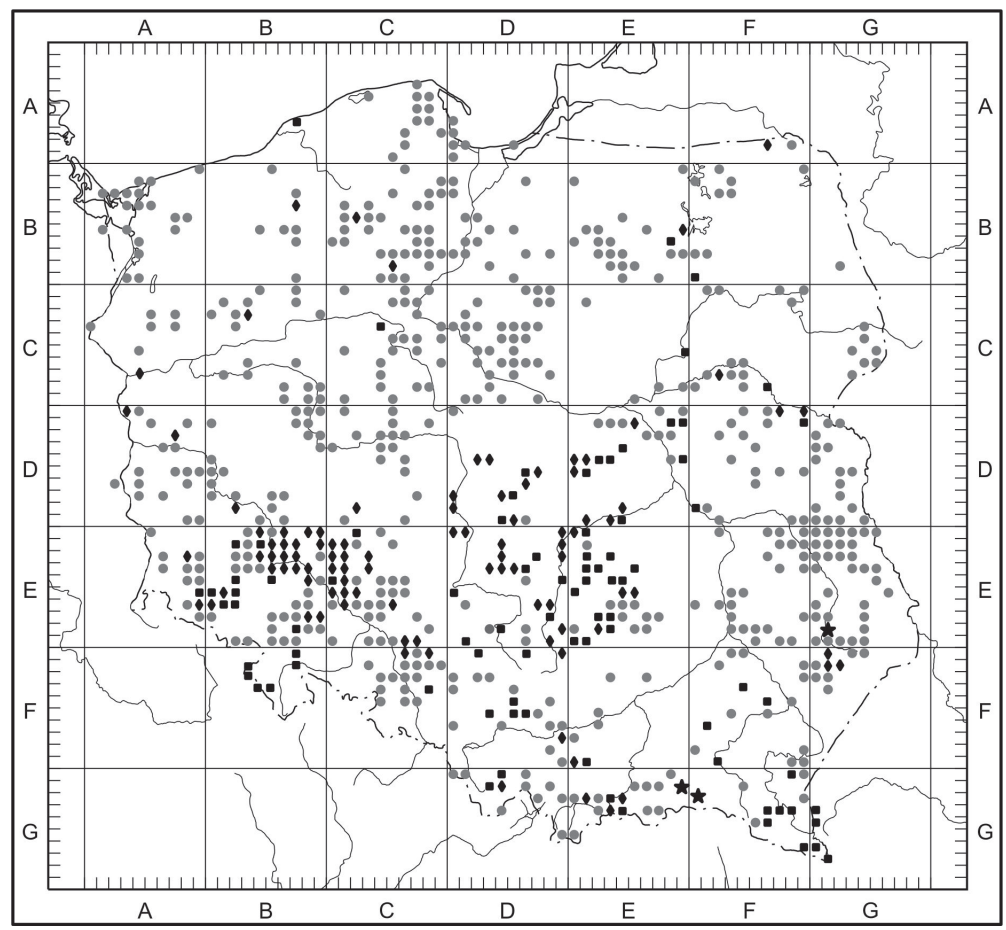

Ryc. 2. Rozmieszczenie Ophioglossum vulgatum w Polsce: $\star$ - nowe stanowiska, opisane w niniejszej pracy, • - stanowiska sprzed 2000 r., $\bullet$ - stanowiska znalezione po 2000 r., - - stanowiska nowe w stosunku do mapy rozmieszczenia Zamieszczonej w publikacji ZAJĄC \& ZAJĄC (2001)

Fig. 2. Distribution of Ophioglossum vulgatum in Poland: $\star-$ new localities, given in this paper, $\bullet-$ localities prior to 2000, - localities found after 2000, - new localities not on the distribution map included in ZAJACC \& ZAJACC (2001) 
Arrhenatherum elatius, Betonica officinalis, Carex pilulifera, Centaurea jacea, Crepis biennis, Dactylorhiza majalis, Daucus carota, Heracleum sphondyllium, Holcus lanatus, Hypericum perforatum, Lathyrus pratensis, Leontodon hispidus, Leucanthemum vulgare, Listera ovata, Lotus corniculatus, Luzula campestris, Plantago lanceolata, Prunella vulgaris, Ranunculus acris, Rhinanthus serotinus, Taraxacum officinale, Trifolium pratense i Veronica chamaedrys. Populacja liczyła 35 osobników, z czego 29 wykształciło kłosy zarodnionośne (Ryc. 1).

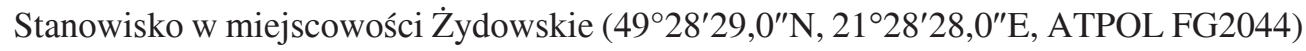
położone jest na wysokości $460 \mathrm{~m}$ n.p.m., na stoku o nachyleniu $5^{\circ} \mathrm{i}$ wystawie południowo-zachodniej, przy ścieżce obok miejsca dawnej lokalizacji cerkwi. Ophioglossum vulgatum zajmował tam siedlisko łąki wilgotnej z klasy Molinio-Arrhenatheretea, gdzie dominowała Dactylis glomerata. Obok rosły: Achillea millefolium, Cerastium holosteoides, Cirsium rivulare, Colchicum autumnale, Crepis biennis, Daucus carota, Eriophorum latifolium, Phleum pratense, Plantago lanceolata, Ranunculus acris, Rumex crispus, Taraxacum officinale oraz Trifolium pratense. Populacja liczyła 20 osobników, z czego większość wykształciła kłosy zarodnionośne.

$\mathrm{Na}$ stanowisku w miejscowości Klemensów $\left(50^{\circ} 42^{\prime} 51,5^{\prime \prime} \mathrm{N}, 2^{\circ} 01^{\prime} 25,0^{\prime \prime} \mathrm{E}\right.$, ATPOL GE8122). Ophioglossum vulgatum rósł na wilgotnej łące z klasy Molinio-Arrhenatheretea, przy starorzeczu rzeki Wieprz. W zbiorowisku dominowała Festuca rubra i Avenula pubescens. Poza wymienionymi trawami odnotowano: Achillea millefolium, Alchemilla sp., Cirsium rivulare, Cerastium holosteoides, Cirsium vulgare, Dactylis glomerata, Dactylorhiza majalis, Equisetum palustre, Galium mollugo, Geum rivale, Heracleum sphondyllium, Lathyrus pratensis, Lotus corniculatus, Lychnis flos-cuculi, Lysimachia nummularia, Poa pratensis, Phalaris arundinacea, Ranunculus repens, Taraxacum officinale i Veronica chamaedrys. Populacja liczyła 50 osobników, z czego większość wykształciła kłosy zarodnionośne.

\section{UAKTUALNIONE ROZMIESZCZENIE OPhioglossum VULGATUM W POLSCE}

Analiza danych $\mathrm{z}$ literatury oraz danych zamieszczonych w bazie RAR wykazała łącznie 707 stanowisk Ophioglossum vulgatum na terenie Polski. $187 \mathrm{z}$ nich zostało stwierdzonych lub potwierdzonych po 2000 r. (Ryc. 2, Tab. 1).

Wśród stanowisk stwierdzonych po 2000 r. znajdują się zupełnie nowe, a ich liczba wynosi 88 (np. KowAlCZYK 2005; SITEK i in. 2019). Najwięcej nowych stanowisk odnaleziono w Polsce południowej. Są to również stanowiska potwierdzane, odnalezione przez badawczy we wcześniejszych latach. Ich liczba wynosi 99. Przykładem może być praca KOZAKA (2007), który potwierdził stanowisko z doliny Jaszcze notowane przez KoRNASIA (1963). Podobnie ORZECHOWSKI i in. (2016) potwierdzili stanowiska podawane w starszych pracach DECKER'A (1911) i STRECH'A $(1935,1937)$. W publikacjach pojawiają się również informacje dotyczące zanikania stanowisk gatunku (temat rozwinięty w dyskusji). 


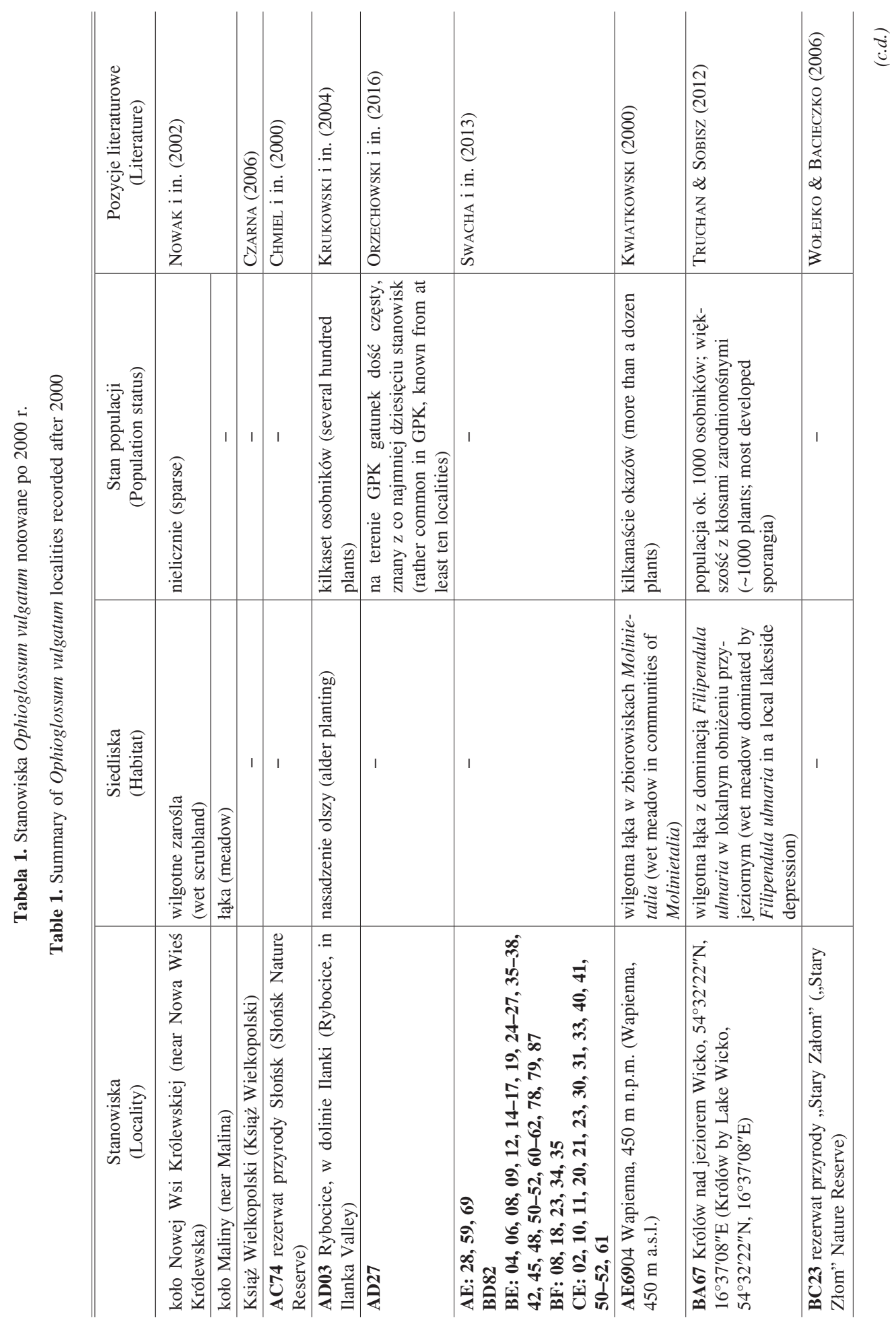




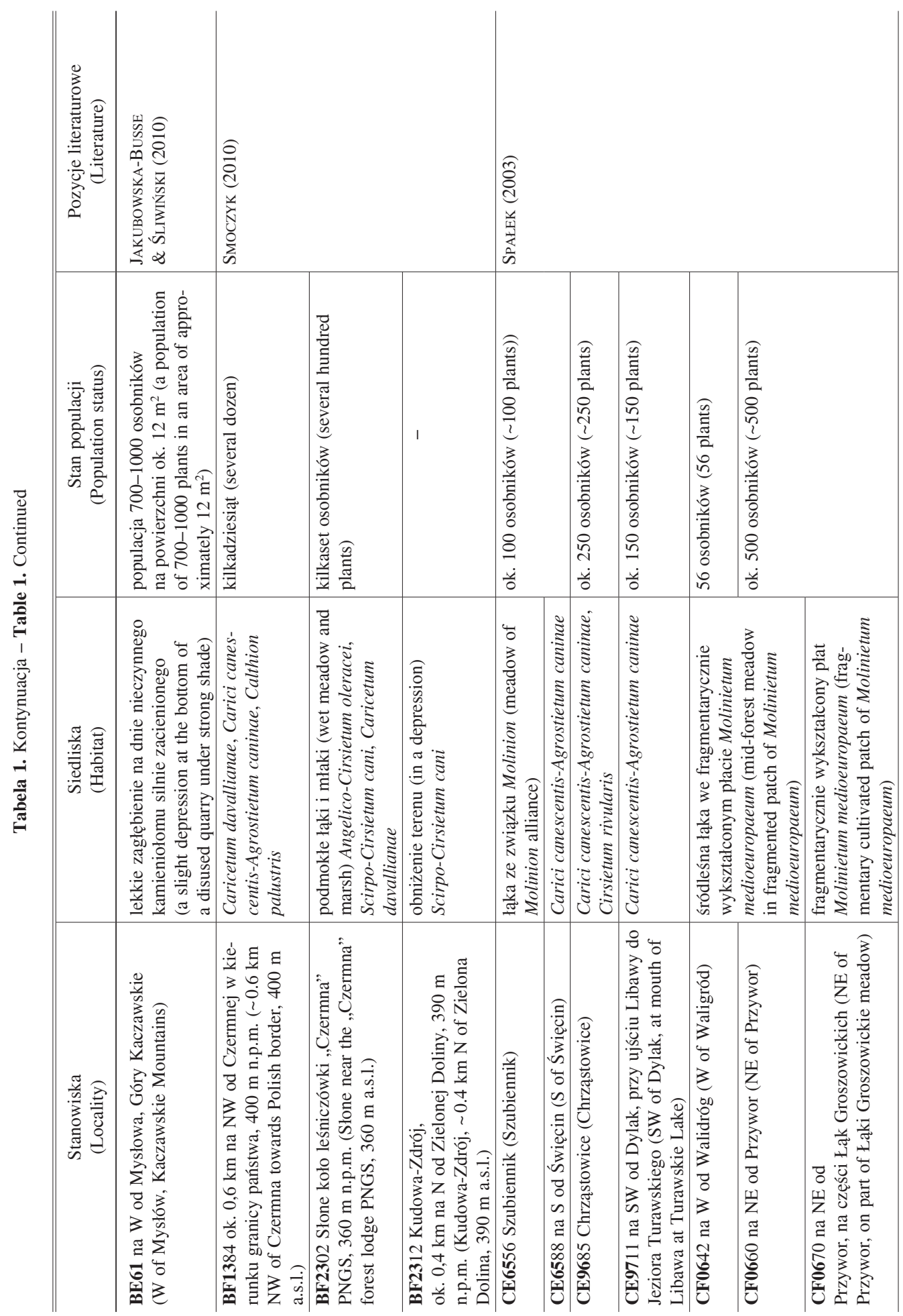




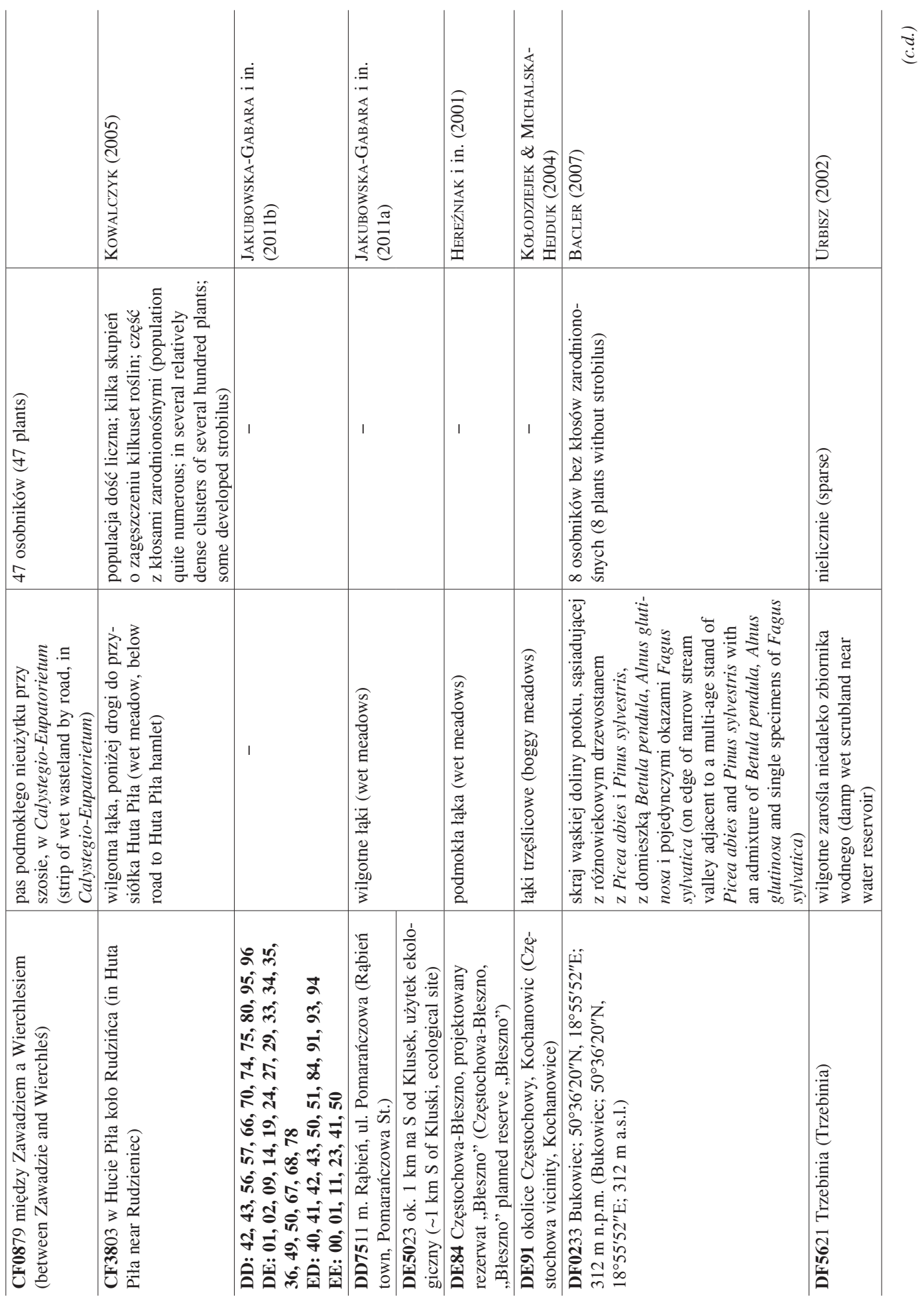




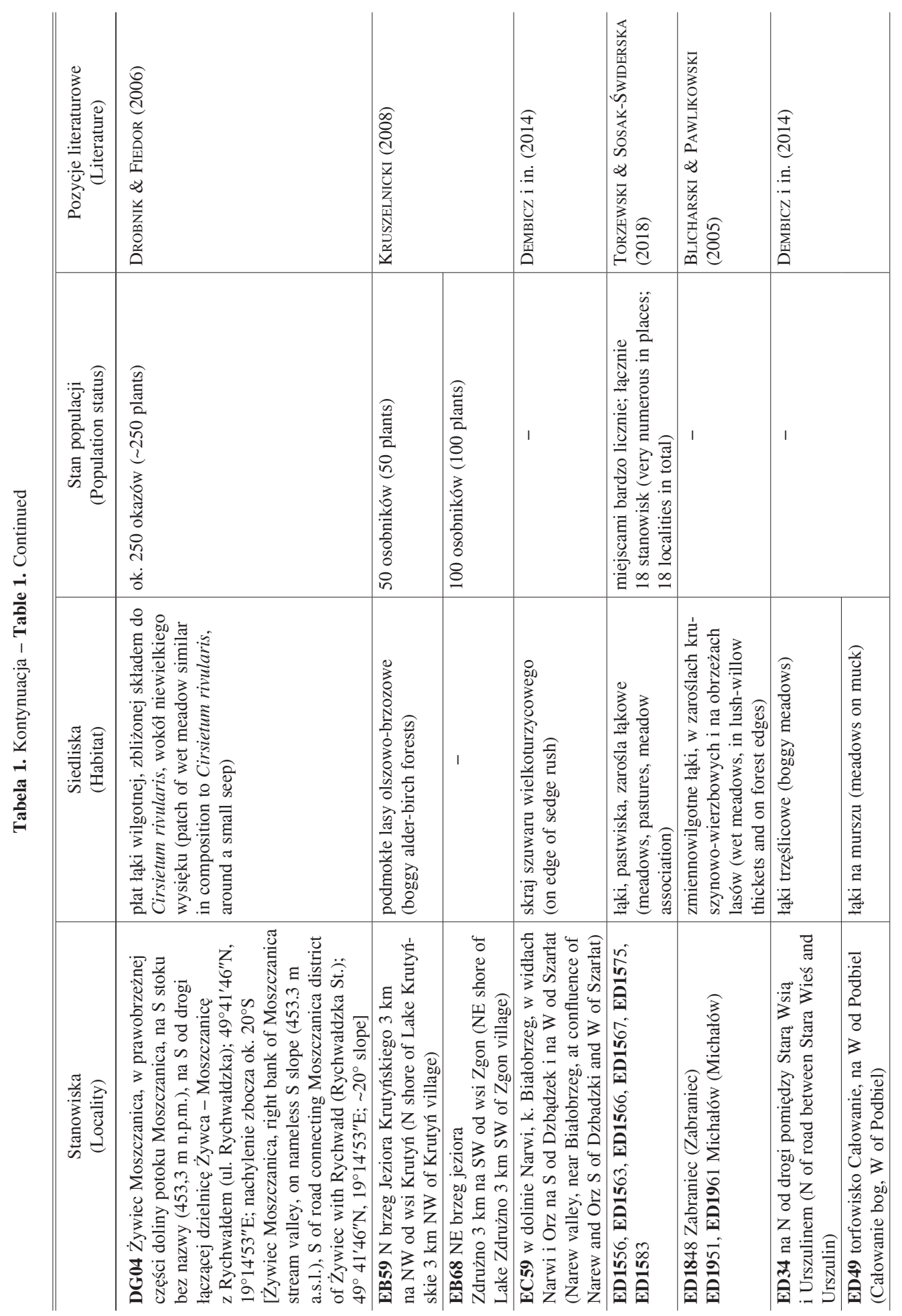




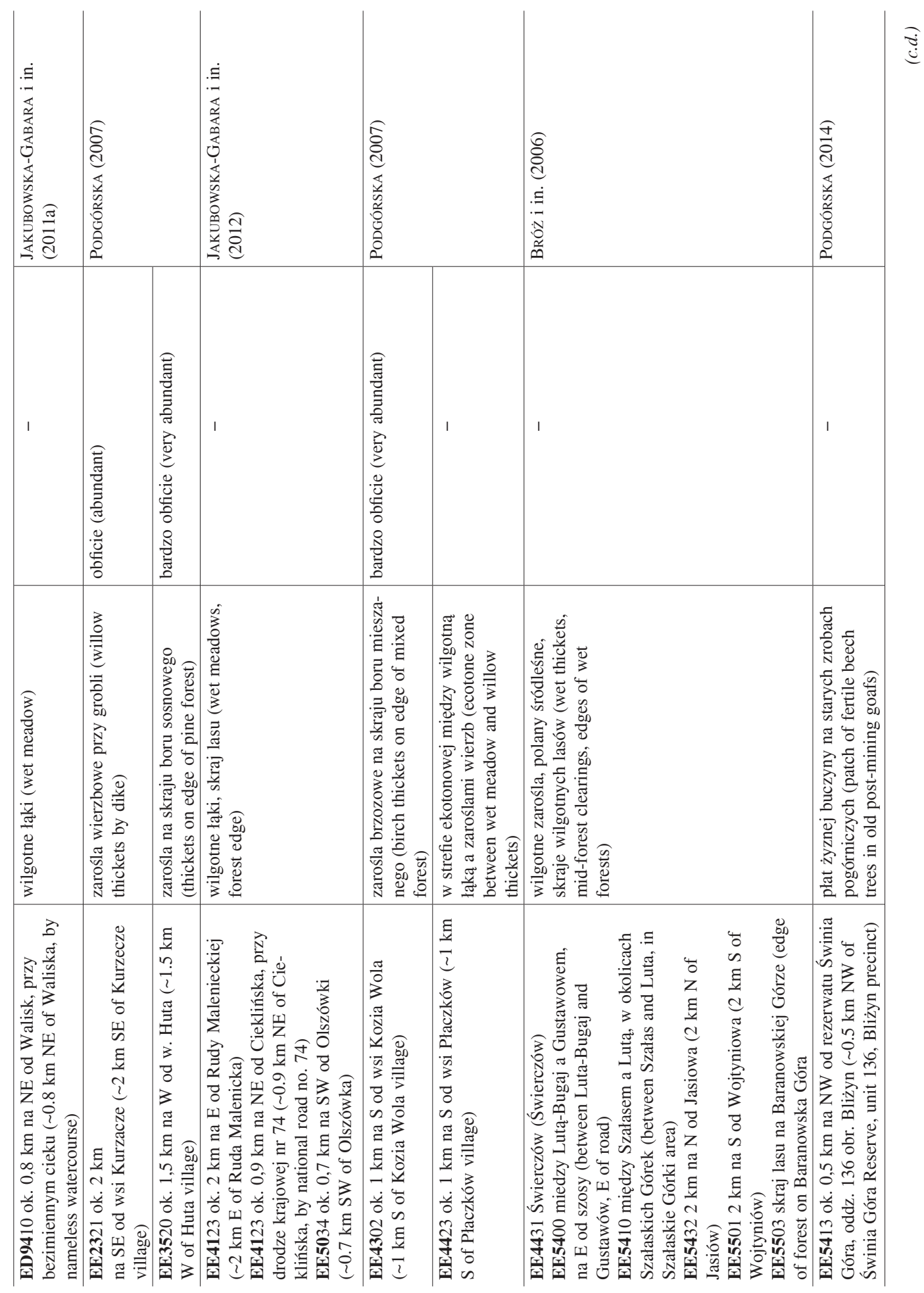




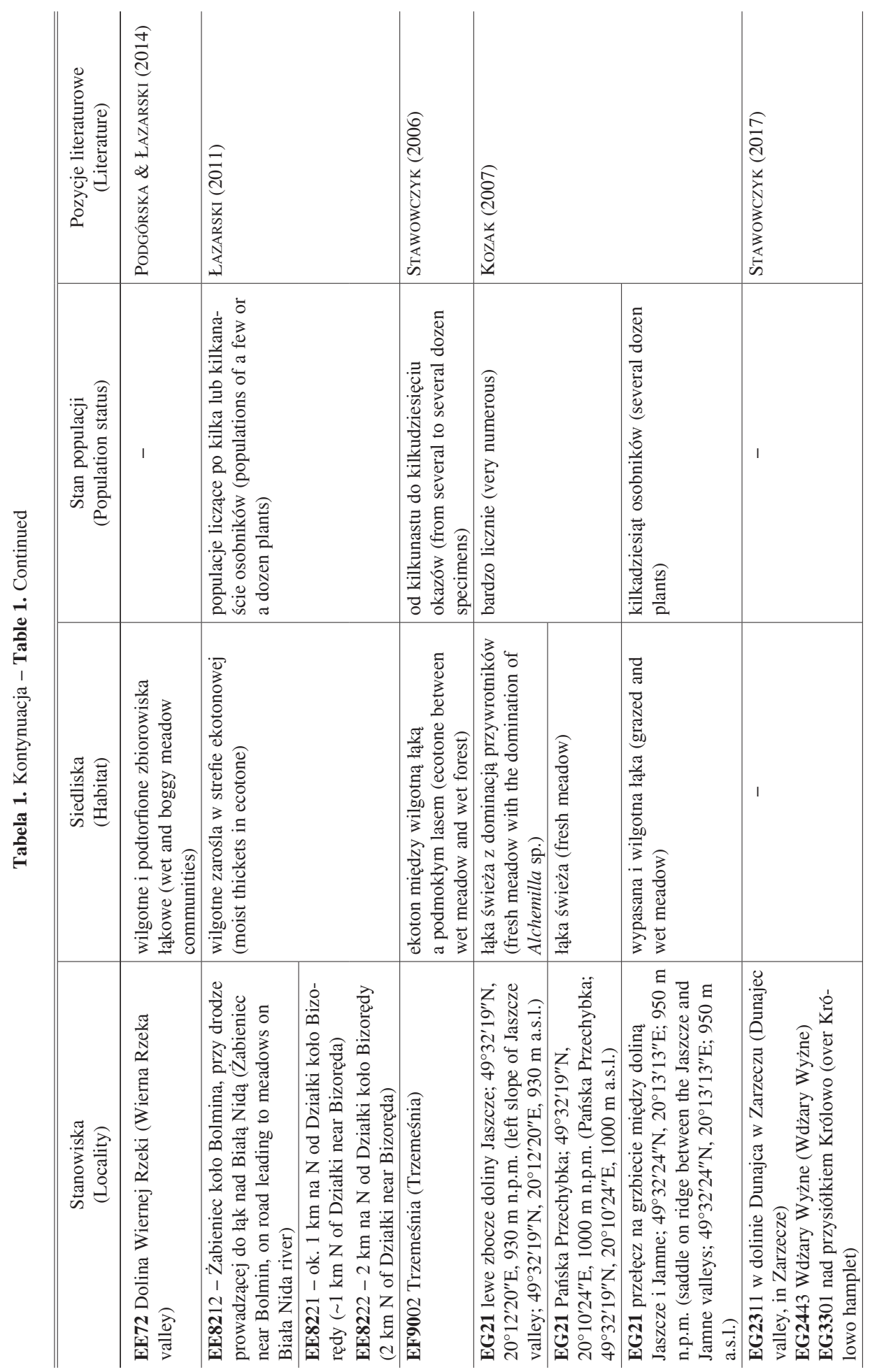




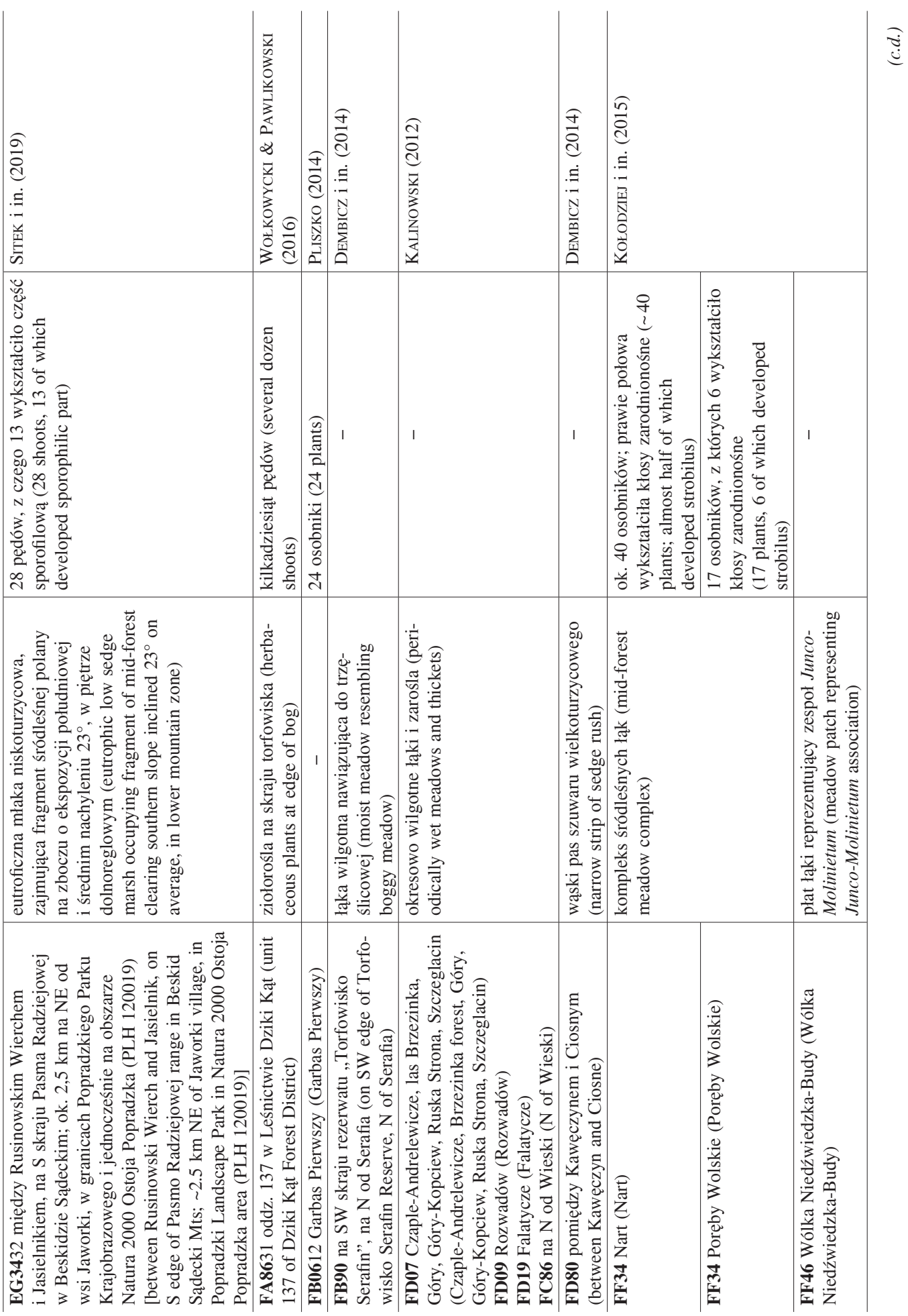




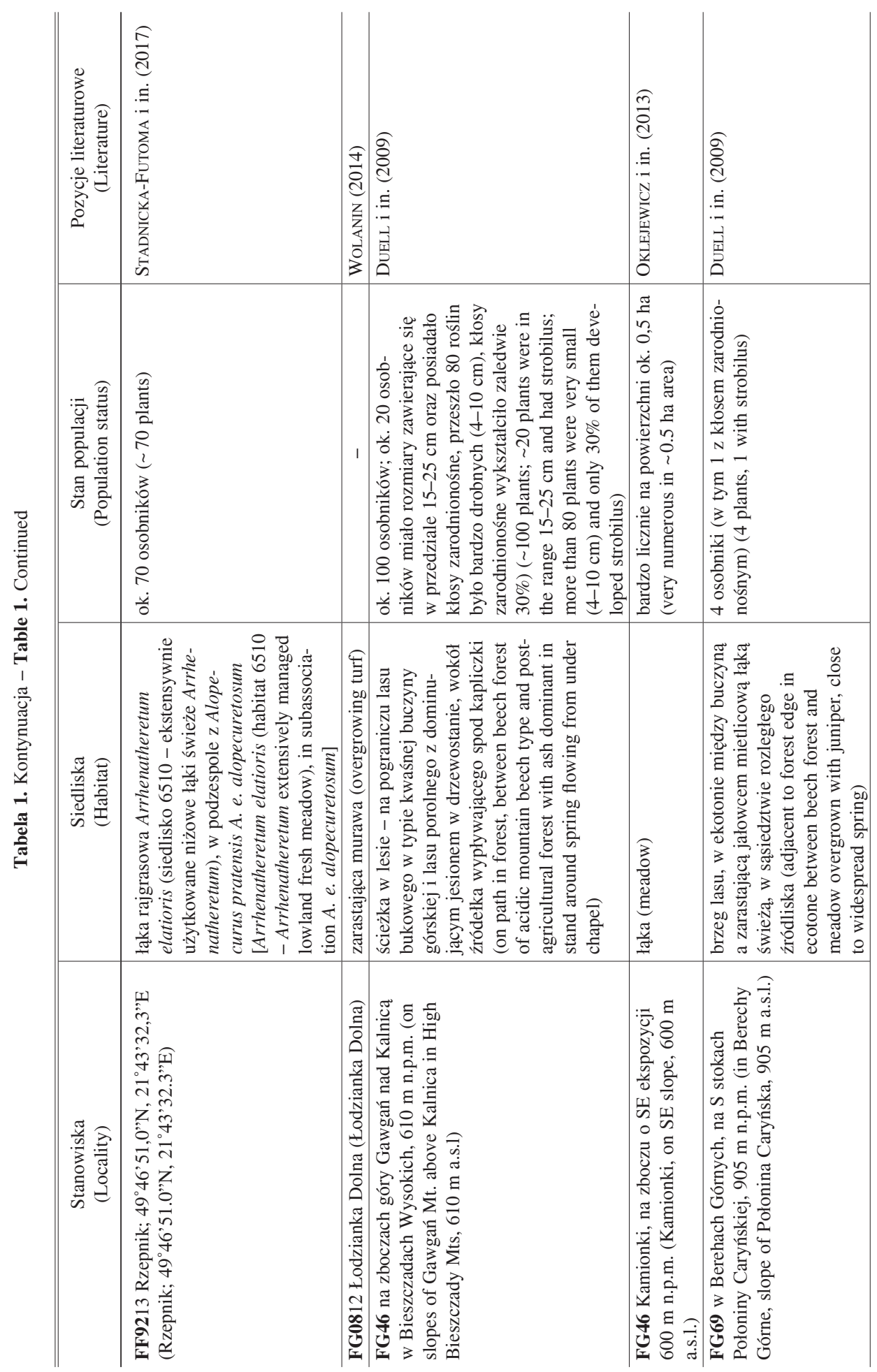




\begin{tabular}{|c|c|c|c|c|c|}
\hline & \multicolumn{2}{|l|}{ 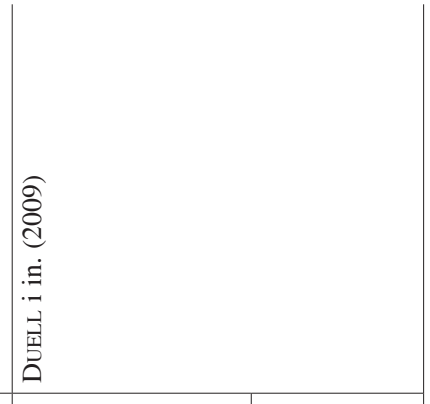 } & \multirow{4}{*}{ 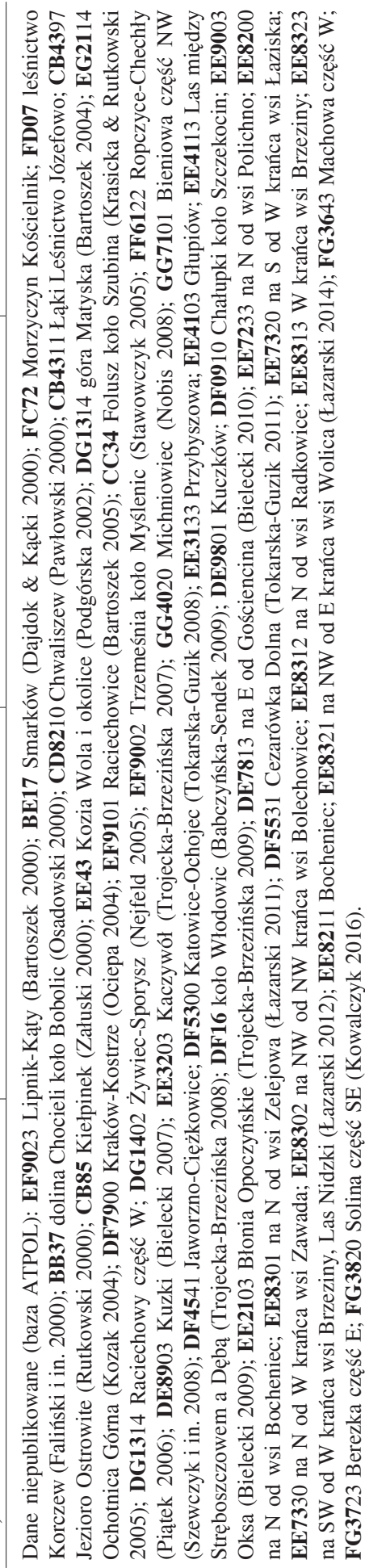 } \\
\hline 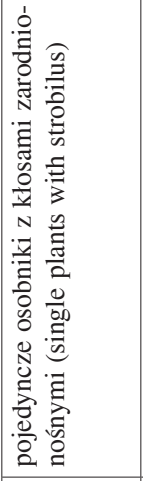 & 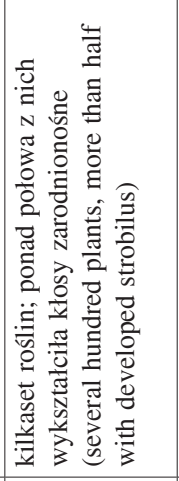 & 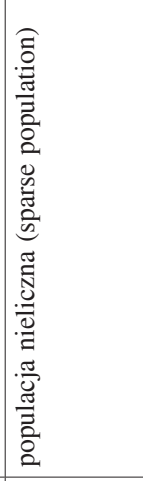 & 1 & 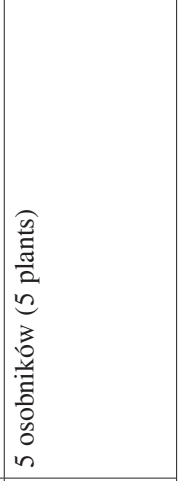 & \\
\hline 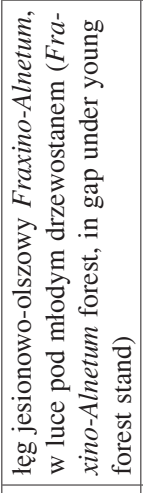 & 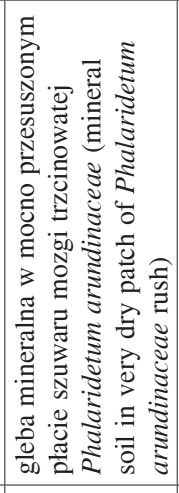 & 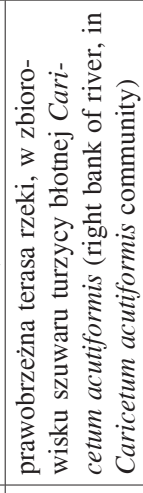 & 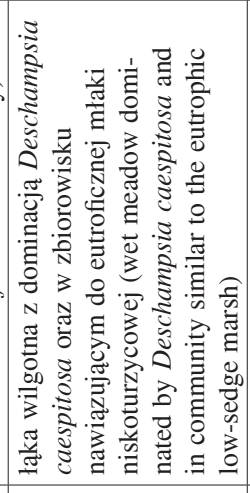 & 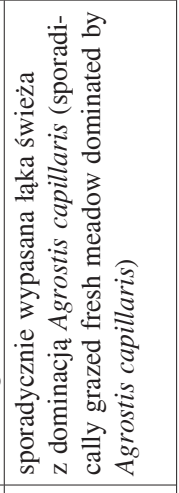 & \\
\hline 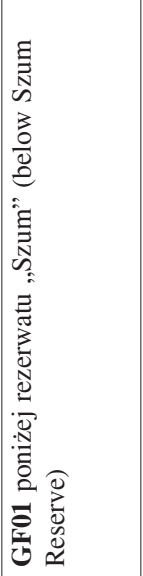 & 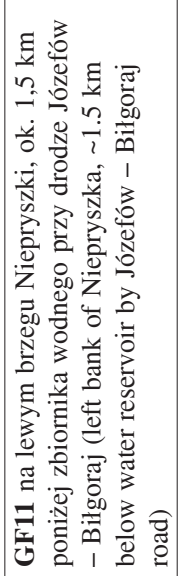 & 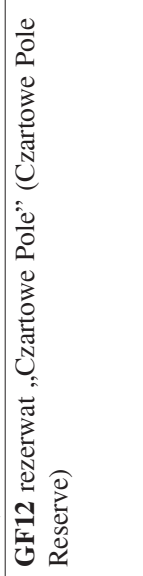 & 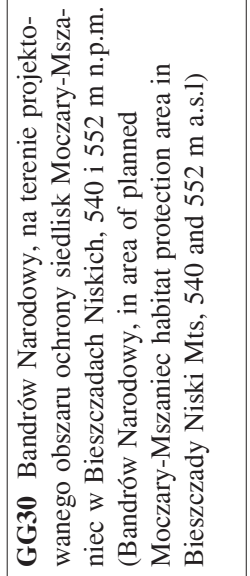 & 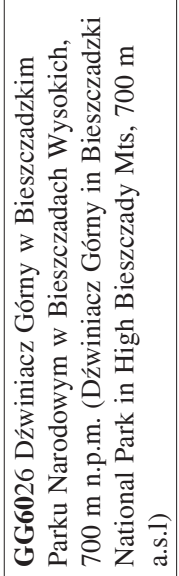 & \\
\hline
\end{tabular}




\section{DYSKUSJA}

Najstarsze notowania Ophioglossum vulgatum na terenie Polski pochodzą z XIX w. z okolic Łężyna (BÄNITZ 1865). Później nasięźrzał pospolity podawany był np. z kilku stanowisk z Pogórza Przemyskiego i Dynowskiego (KotUla 1881). Ponad 50 stanowisk, głównie z Pojezierza Południowobałtyckiego, zamieszczonych zostało w pracach ABRoMEITA (1928) oraz Abromeita i in. (1940, 1989). Znaczącą liczbę stanowisk wymienia Schube $(1903,1904)$ z południowo-zachodniej Polski. Wiele stanowisk stwierdzano w latach 1950-1999, w tym około 100 niepublikowanych z południowej Polski zanotował D. Fijałkowski.

Ophioglossum vulgatum jest rośliną o niewielkich rozmiarach, którą łatwo przeoczyć. Najlepiej zauważalna jest w okresie od końca maja do lipca, kiedy posiada dobrze wykształcone kłosy zarodnionośne. Wiosną część asymilacyjna przypomina liście innych roślin, których kształt jest owalny, a później cała nadziemna część rośliny usycha i zanika (UHLIAROWÁ 2005). JAKUBOWSKA-BUSSE i ŚLIWIŃSKI (2010) piszą o problemie niedoszacowania rzeczywistej liczby stanowisk nasięźrzału i przypuszczają, że może ich być znacznie więcej. Niemniej, jak wynika z aktualnych obserwacji, gatunek ma tendencję do zanikania (SwACH i in. 2013). Po przeanalizowaniu notowań z bazy danych ATPOL, materiałów zielnikowych, a także na podstawie danych własnych autorów oraz danych z literaty wywnioskowano, że na 73 podawane stanowiska, jedynie 54 są aktualne, natomiast pozostałe nie zostały potwierdzone. Doniesienia o zanikaniu gatunku pojawiają się w wielu opracowaniach. DuEll i in. (2009) piszą o dwóch stanowiskach z Krościenka podawanych przez KotUlE (1883), które nie zostały potwierdzone w badaniach ZEMANKA (1989). SiteK i in. (2019) także wspominają o dwóch nieistniejących stanowiskach notowanych przez PAwŁowsKIEGO (1925) z Roztoki Wielkiej i Chełmca. NIEDźwIECKA (2006) nie potwierdziła stanowiska podawanego przez Kotulę (1881) z Pogórza Dynowskiego. Są to tylko przykłady prac traktujących o ustępowaniu gatunku. Ponadto zdarza się, że nawet nowe stanowiska nie mają szans przetrwania, czy to z powodów zbyt małych populacji (DuELL i in. 2009), czy też niesprzyjających, niestabilnych warunków siedliskowych (KOwALCZYK 2005; BACLER 2007). Z tych m.in. powodów Ophioglossum vulgatum został uznany w Polsce za zagrożony (KAŹMIERCZAKOWA i in. 2016).

Analizując opracowaną mapę rozmieszczenia (Ryc. 2) można stwierdzić, że spośród 707 stanowisk nasięźrzału pospolitego podanych z terenu Polski, dane o 520 pochodzą sprzed 2000 r. i nie były potwierdzane we współczesnej literaturze (być może wiele z nich już nie istnieje). Z kolei 99 stanowisk ma potwierdzenie w opracowaniach publikowanych po 2000 r., a 88 jest nowych w stosunku do mapy rozmieszczania z pracy ZAJAcA i ZAJĄC (2001) (w tym trzy opisywane w niniejszej pracy). Gatunek ciągle spotykany jest na terenie całego kraju, jednak zdecydowanie więcej stanowisk (po 2000 r.) opublikowano z części centralnej i południowej, natomiast niewiele danych pochodzi z Polski północnej. Trudno jednoznacznie stwierdzić czy wynika to z faktu, że gatunek tam zanika. Może to być efektem braku dokładnych badań florystycznych, które obecnie stają się coraz mniej popularne. Aby móc wyciągać uprawnione wnioski konieczne byłyby gruntowe badania nad rozmieszczeniem Ophioglossum vulgatum, w tym weryfikacja jego 
wszystkich stanowisk (jak w opracowaniu SwACH i in. 2013) i być może badania populacyjne na wybranych stanowiskach, które pozwoliłyby na określenie kondycji populacji gatunku na terenie kraju.

Do 2000 r. na terenie Beskidu Niskiego odnotowano trzy stanowiska Ophioglossum vulgatum. Dwa z nich podaje Мотүка (1956) z kwadratów: EG16 (Siółków) oraz EG17 (Grybów, Kąclowa), natomiast jedno z kwadratu FG45 (Komańcza) wymienia GrodzIŃSKA (1968). W przypadku Kotliny Zamojskiej dwa stanowiska stwierdzone zostały przez D. Fijałkowskiego w II poł. XX w. z kwadratów: GE71 (Nielisz) i GE92 (Lipsko, Wieprzec), przy czym są to dane niepublikowane z bazy RAR. Nowe stanowiska są zatem pierwszymi, stwierdzonymi po 2000 r. na terenie obu mezoregionów.

Warto zwrócić uwagę, że nie tylko w Polsce nasięźrzał pospolity jest rzadką rośliną. Do krytycznie zagrożonych gatunków został zaliczony również we florze słowackiej, gdzie posiada kategorię EN (FerÁKOvá i in. 2001). Pomimo znajdywania nowych stanowisk przy okazji mapowania roślinności użytków zielonych i torfowisk, ogólna ich liczba jest niewielka (UhLIAROWÁ 2005). Ophioglossum vulgatum jest klasyfikowany jako zagrożony z kategorią EN - zagrożony także na terenie Czech (GRULICH 2012), gdzie zaniknął głównie na skutek zmiany użytkowania gruntów (KAPLAN i in. 2017). Gatunek zanika też na Ukrainie. Przed 1980 r. notowano go w 152 miejscach, po 1980 r. - 120. Podstawowym czynnikiem powodującym zmniejszanie się liczby stanowisk jest wzrost antropopresji. Niemniej jednak do tej pory gatunek nie został umieszczony w Czerwonej księdze roślin Ukrainy (PARNIKOZA i in. 2017).

Głównym zagrożeniem dla występowania nasięźrzału pospolitego jest zanikanie siedlisk, w szczególności łąk. Może to nastąić na skutek zaniechania koszenia lub też z powodu zabiegów melioracyjnych, które prowadzą do osuszenia terenu (DROBNIK \& FIEDOR 2006). W przypadku trzech nowych stanowisk najmniej zagrożone jest stanowisko w Żydowskim, ponieważ znajduje się na łące leżącej w obrębie Magurskiego Parku Narodowego, gdzie podlega ochronie czynnej. Stanowisko położone w Bednarce znajduje się na łące świeżej, która graniczy z zaroślami. W związku z tym, w przypadku zaprzestania koszenia, szybko zarośnie drzewami i krzewami. Jednak dużą szansą na zachowanie populacji jest jej położenie w obszarze Natura 2000 Bednarka PLH120033 i fakt, że siedliska łąkowe 6510, w których odnotowano gatunek mają zostać zaklasyfikowane jako przedmiot ochrony. Trzecie stanowisko, z Klemensowa, jest najbardziej zagrożone, ponieważ znajduje się w obrębie niekoszonej łąki, na której rozpoczyna się ekspansja krzewów.

Podsumowując, Ophioglossum vulgatum należy do roślin rzadkich w skali kraju, a ponadto siedliskowo związany jest głównie z terenami podmokłymi, które sukcesywnie znikają z polskiego krajobrazu. Pomimo tego trudno jednoznacznie określić skalę tego zjawiska. Zmniejszenie liczby stanowisk może wynikać z braku - jak wspomniano - popularności badań florystycznych oraz trudności w odnalezieniu okazów nasięźrzału w okresie wegetacyjnym. W związku z tym kwestia rozmieszczenia i stanu zachowania populacji O. vulgatum wymaga dalszych, szczegółowych badań.

Podziękowania. Autorzy składają podziękowania prof. dr. hab. Adamowi Zającowi za udostępnienie informacji o stanowiskach gatunku oraz mapy rozmieszczenia z bazy ATPOL. 


\section{LITERATURA}

AвRomeit J. 1928. Neue und bemerkenswertere Pflanzenfunde in Ostpreussen und den benachbarten Gebieten. - Schriften der königlichen physikalisch-ökonomischen Gesellschaft zu Königsberg 65(3/4): $182-238$.

Abromeit J., Jentszch A. \& Vogel G. 1898. Flora von Ost- und Westpreussen. I. Samenpflanzen oder Phanerogamen. ix +1248 . Preussischen Botanischen Verein zu Königsberg in Preussen, Berlin.

Abromeit J., Neuhoff W. \& Stefen H. 1940. Flora von Ost- und Westpreussen. - Kommissionsverlag Gräfe und Unzer 6(56-78): 877-1248.

BACLER B. 2007. Nowe stanowisko nasięźrzału pospolitego Ophioglossum vulgatum L. na Równinie Opolskiej. - Chrońmy Przyrodę Ojczystą 63(2): 15-21.

BäNITZ C. 1865. Beiträge zur Flora des Königreichs Polen. - Schriften der königlichen physikalisch-ökonomischen Gesellschaft zu Königsberg 16(2): 77-103.

Blicharski M. \& PAWLIKOWSKI P. 2005. Rzadkie i interesujące gatunki roślin naczyniowych poligonu wojskowego w lasach rembertowsko-okuniewskich pod Warszawą. - Fragmenta Floristica et Geobotanica Polonica 12(1): 83-96.

BRÓż E., PODGóRSKA M. \& PRZEMYSKI A. 2006. Nowe stanowiska rzadkich, chronionych oraz zagrożonych gatunków roślin naczyniowych na Płaskowyżu Suchedniowskim (Wyżyna Małopolska). - Fragmenta Floristica et Geobotanica Polonica 13(1): 55-65.

Chmiel J., Jackowiak B., Latowski K. \& Żukowski W. 2000. The vascular plants of the Słońsk Nature Reserve (Western Poland). - Biological Bulletin of Poznań 37(2): 205-233.

CZARnA A. 2006. Flora of vascular plants in Książ Wielkopolski commune (Central Wielkopolska). - Roczniki Akademii Rolniczej w Poznaniu, Botanica-Steciana 10: 47-68.

CZARneCKA B. 2003. Nowe stanowisko nasięźrzału pospolitego Ophioglossum vulgatum w dolinach rzecznych strefy krawędziowej Roztocza Tomaszowskiego. - Chrońmy Przyrodę Ojczystą 59(6): 85-89.

DECKER P. 1911. Beiträge zur Flora der südlichen Neumark und der östlichen Niderlausitz. - Verhandlungen botanischen Vereins der Provinz Brandenburg 53: 87-269.

Dembicz I., Kozub Ł., Brzezińska K., Zaniewski P., Jarzombkowski F. \& PióRKowski H. 2014. Stanowiska rzadkich i zagrożonych gatunków roślin naczyniowych terenów otwartych północnej i środkowej części Niziny Mazowieckiej. - Fragmenta Floristica et Geobotanica Polonica 21(2): 287-303.

DrobNiK J. \& Fiedor M. 2006. Nowe stanowisko nasięźrzału pospolitego Ophioglossum vulgatum (Ophioglossaceae) w Kotlinie Żywieckiej. - Fragmenta Floristica et Geobotanica Polonica 13(1): 222-224.

Duell J., Celina M. \& KucharzyK S. 2009. Nasięźrzał pospolity Ophioglossum vulgatum L. - nowe stanowiska w Bieszczadach Zachodnich. - Chrońmy Przyrodę Ojczystą 65(5): 385-388.

FerÁKOVÁ, V., MAGLOCKÝ Š. \& MARHOLD K. 2001. Červený zoznam paprad’orastov a semenných rastlín Slovenska. - Ochrana Prírody (Banská Bystrica) 20: 48-81.

GrodzińsKa K. 1968. Rośliny naczyniowe Pasma Bukowicy (Beskid Niski). - Fragmenta Floristica et Geobotanica 14(1): 3-82.

GRULICH V. 2012. Red List of vascular plants of the Czech Republic: 3rd edition. - Preslia 84: 631-645.

Hereźniak J., Grzyl A., KołodzieJeK J. \& Ławrynowicz M. 2001. Materiały do flory północnej części Wyżyny Śląsko-Krakowskiej - rzadkie i interesujące gatunki roślin naczyniowych. Cz. 2. - Fragmenta Floristica et Geobotanica Polonica 8: 35-41.

JAKUBOwSKA-BusSE A. \& ŚLIwIŃSKi M. 2010. Nowe stanowisko nasięźrzału pospolitego Ophioglossum vulgatum L. (Ophioglossaceae) na Dolnym Śląsku. - Acta Botanica Silesiaca 5: 107-110. 
Jakubowska-Gabara J., Kucharski L., Kiedrzyński M., WitosŁawski P., ZielińsKa K., KoŁodZiejeK J., GrzYL A. \& PoPKIEWICZ P. 2011a. Nowe stanowiska rzadkich, chronionych i zagrożonych gatunków roślin naczyniowych w Polsce środkowej. - Fragmenta Floristica et Geobotanica Polonica 18(1): 29-38.

Jakubowska-Gabara J., Kucharski L., Zielińska K., Kolodziejek J., WitosŁawski P. \& Popkiewicz P. 2011b. Atlas rozmieszczenia roślin naczyniowych w Polsce Środkowej. Gatunki chronione, rzadkie, ginące i narażone. s. 283. Wydawnictwo Uniwersytetu Łódzkiego, Łódź.

Jakubowska-Gabara J., KurZac M., KiedrzyŃski M., Kopeć D., Kucharski L., KołodzieJek J., NiedźWIEDZKi P., PoPKIEWICZ P., WitosŁAWSKI P. \& ZIELIŃSKA K. 2012. Nowe stanowiska rzadkich, chronionych i zagrożonych gatunków roślin naczyniowych w Polsce Środkowej. Cz. II. - Fragmenta Floristica et Geobotanica Polonica 19(2): 349-359.

KaLINOwSKi P. 2012. Rzadkie rośliny naczyniowe Podlasia Nadbużańskiego - cz. 1. Gatunki siedlisk murawowych, łąkowych i szuwarowych. - Fragmenta Floristica et Geobotanica Polonica 19(2): 361-377.

Kaplan Z., Danihelka J., KouteckÝ P., Šumberová K., Ekrt L., Grulich V. Řepka R., Hroudová Z., ŠtěPÁnková J., DvoŘÁK V., DanČÁK M., Dřevojan P. \& Wild J. 2017. Distributions of vascular plants in the Czech Republic. Part 4. - Preslia 89: 115-201.

Kaźmierczakowa R., Bloch-OrŁowska J., Celka Z., Cwener A., Dajdok Z., Michalska-Hejduk D., PAWLIKowsKi P., SzCZ̨ŚNIAK E. \& ZIARNeK K. 2016. Polska czerwona lista paprotników i roślin kwiatowych. s. 44. Instytut Ochrony Przyrody Polskiej Akademii Nauk, Kraków.

KoŁodziej Z., Bilański P. \& PAJĄK M. 2015. Nowe stanowiska nasięźrzału pospolitego Ophioglossum vulgatum na Płaskowyżu Kolbuszowskim. - Chrońmy Przyrodę Ojczystą 71(6): 467-469.

KołodziejeK J. \& Michalska-Hejduk D. 2004. Charakterystyka geobotaniczna łąk trzęślicowych Molinietum caeruleae na polanach śródleśnych północnej części województwa śląskiego. - Fragmenta Floristica et Geobotanica Polonica 11: 141-155.

KoRnAŚ J. 1963. Rośliny naczyniowe Gorców. Uzupełnienie I. - Fragmenta Floristica et Geobotanica Polonica 9(2): 189-202.

KотUla B. 1881. Spis roślin naczyniowych z okolicy Przemyśla. - Sprawozdanie Komisji Fizjograficznej 15: $1-90$.

KотUla B. 1883. Spis roślin naczyniowych z okolic górnego Strwiąża i Sanu, z uwzględnieniem pionowego zasięgu gatunków. - Sprawozdanie Komisyi Fizyjograficznej AU 17: 105-243.

KowalcZYK B. 2005. Nowe stanowisko Botrychium lunaria i Ophioglossum vulgatum (Ophioglossaceae). - Fragmenta Floristica et Geobotanica Polonica 12(1): 184-185.

KozAK M. 2007. Materiały do rozmieszczenia rzadkich, interesujących i zagrożonych gatunków roślin naczyniowych w Gorcach. - Fragmenta Floristica et Geobotanica Polonica 14(2): 249-259.

Krukowski M., SMoczyK M. \& WróBel D. 2004. Notatki florystyczne z doliny Odry. - Fragmenta Floristica et Geobotanica Polonica 11(2): 257-261.

KRUSZELNICKI J. 2008. Stanowiska rzadszych roślin naczyniowych na terenie Mazurskiego Parku Krajobrazowego i jego okolic (Pojezierze Mazurskie). - Fragmenta Floristica et Geobotanica Polonica 15(1): 61-67.

KwiatKowski P. 2000. Notatki florystyczne z Gór Kaczawskich i ich Pogórza (Sudety Zachodnie). - Fragmenta Floristica et Geobotanica Polonica 7: 105-116.

ŁAZARSKI G. 2011. Rzadkie i zagrożone gatunki roślin naczyniowych w dolinie Białej Nidy w pobliżu Małogoszcza (centralna część Wyżyny Małopolskiej). - Fragmenta Floristica et Geobotanica Polonica 18(2): 257-264.

MatuszKiewicz W. 2006. Przewodnik do oznaczania zbiorowisk roślinnych Polski. s. 540. Wydawnictwo Naukowe PWN, Warszawa. 
МотYкA J. 1956. O niektórych rzadszych gatunkach roślin naczyniowych w okolicach Grybowa. - Fragmenta Floristica et Geobotanica 2(1): 3-26.

NiedźwIECKA J. 2006. Flora Pogórza Dynowskiego i jej aspekty fitogeograficzne. Mskr. rozprawy doktorskiej, Instytut Botaniki, Uniwersytet Jagielloński.

NowaK A., NowaK S. \& SpaŁeK K. 2002. Chronione i rzadkie gatunki roślin naczyniowych Opola. - Fragmenta Floristica et Geobotanica Polonica 9: 127-133.

Oklejewicz K., Cencora A., Wolanin M., Marciniuk J., Marciniuk P. \& Scelina M. 2013. Nowe i rzadkie gatunki we florze Bieszczadów. - Roczniki Bieszczadzkie 21: 74-80.

Orzechowski R., Wasielewski H. \& SMOczYK M. 2016. Chronione i zagrożone gatunki flory naczyniowej Gryżyńskiego Parku Krajobrazowego. - W: M. MaCiantowicz (red.), 20 lat - Gryżyński Park Krajobrazowy - Monografia Przyrodnicza, s. 128-143. Zespół Parków Krajobrazowych Województwa Lubuskiego, Gorzów Wielkopolski.

Parnikoza I., Chernyshenko M. \& Celka Z. 2017. Ophioglossaceae (Psilotopsida) in Ukraine. - Biodiversity: Research and Conservation 48: 25-47.

PAWŁOWSKi B. 1925. Geobotaniczne stosunki Sądeczyzny. - Prace Monograficzne Komisji Fizjograficznej PAU 1: $1-342$.

PliszKo A. 2014. Nasięźrzał pospolity Ophioglossum vulgatum w dolinie górnej Rospudy. - Chrońmy Przyrodę Ojczystą 70(4): 355-357.

PoDGÓRSKA M. 2007. Chronione, zagrożone oraz rzadkie gatunki flory naczyniowej Garbu Gielniowskiego (Wyżyna Małopolska). - Fragmenta Floristica et Geobotanica Polonica 14(1): 61-74.

PoDGóRSKA M. 2014. Chronione, zagrożone oraz rzadkie gatunki roślin naczyniowych zrobów pokopalnianych - pozostałości po dawnej eksploatacji rud żelaza na północnym przedpolu Gór Świętokrzyskich (Wyżyna Małopolska). Część I. - Fragmenta Floristica et Geobotanica Polonica 21(2): 241-251.

RozPORZĄDZENIE Ministra Środowiska z dnia 9 października 2014 r. w sprawie ochrony gatunkowej roślin (Dz. U. z 2014 r., poz. 1409).

SchubE T. 1903. Die Verbreitung der Gefässpflanzen in Schlesien preusischen und österreichischen Anteils. s. 363. R. Nischowsky, Breslau.

SchuBE T. 1904. Die Ergebnisse der Durchforschung der schlesischen Gefässpflanzenwelt im Jahre 1903. - Jahres-Bericht Der Schlesischen Gesellschaft für Vaterländische Cultur 81: 42-64.

Sitek E., NowaK B. \& GaJewski Z. 2019. Nowe stanowisko Ophioglossum vulgatum w Beskidzie Sądeckim. - Fragmenta Floristica et Geobotanica Polonica 26(1): 154-159.

Smith A. R., Pryer K. M., Schuettpelz E., Korall P., Schneider H. \& Wolf P. G. 2006. A classification for extant ferns. - Taxon 55(3): 705-731.

Smoczyk M. 2010. Rzadkie i zagrożone rośliny naczyniowe Pogórza Orlickiego (Sudety Środkowe) - cz. 1. - Przyroda Sudetów 13: 53-70.

SpaŁeK K. 2003. Materiały do rozmieszczenia rzadkich i interesujących gatunków paprotników (Pteridophyta) na Równinie Opolskiej. - Fragmenta Floristica et Geobotanica Polonica 10: 209-220.

Stadnicka-Futoma A., Jaźwa M., Węgrzyn M. \& Wietrzyk P. 2017. Nowe stanowisko Ophioglossum vulgatum (Ophioglossaceae) na Pogórzu Dynowskim (SE Polska). - Fragmenta Floristica et Geobotanica Polonica 24(1): 157-202.

STAwowcZYK 2006. Notatki florystyczne z południowo-zachodniej części Pogórza Wielickiego. - Fragmenta Floristica et Geobotanica Polonica 13(2): 420-422.

StawowczYK K. 2017. Flora roślin naczyniowych Pasma Radziejowej w Beskidzie Sądeckim. s. 409. Polska Akademia Nauk - Komitet Biologii Organizmalnej, Instytut Botaniki Uniwersytetu Jagiellońskiego, Warszawa - Kraków. 
Strech A. 1935. Von den Pflanzenwelt des Grieseltals. - Naturdenkmalpflege und Naturschutz in Berlin und Brandenburg 23: 7-11.

Strech A. 1937. Die Naturdenkmäler des Grieseltals. - Naturdenkmalpflege und Naturschultz in Berlin und Brandenburg 32: 330-333.

Swach G., CzARniecKa M. \& KąCKI Z. 2013. Rozmieszczenie, kategoria zagrożenia oraz udział w zbiorowiskach roślinnych Ophioglossum vulgatum L. na terenie Dolnego Śląska. - Acta Botanica Silesiaca 9: $75-96$.

Tląka D. \& Rostański A. 2012. Paprotniki Polski. s. 64. Wydawnictwo „Kubajak”, Kraków.

TORZEWSKI K. \& SOSAK-ŚWIDERSKA B. 2018. Zagrożone, chronione i rzadkie rośliny naczyniowe wschodniej części otuliny Kampinoskiego Parku Narodowego. - Fragmenta Floristica et Geobotanica Polonica 25(1): 53-63.

TRuChan M. \& SoBISz Z. 2012. Nasięźrzał pospolity Ophioglossum vulgatum - nowe stanowisko na Pomorzu Środkowym. - Chrońmy Przyrodę Ojczystą 68(6): 466-468.

UhLIAROVÁ E. 2005. Nová lokalita hadivky obyčajnej (Ophioglossum vulgatum) v Kremnických horách [A new locality of the species Ophioglossum vulgatum in the Kremnické hory Mts]. - Bulletin Slovenskiej Botanickej Spoločnosti 27: 147-150.

URBISZ A. 2002. Nowe stanowiska rzadkich roślin naczyniowych na terenie Jury Krakowsko-Częstochowskiej. - Fragmenta Floristica et Geobotanica Polonica 9: 141-146.

Wolanin M. 2014. Rośliny naczyniowe Pogórza Przemyskiego i zachodniej części Płaskowyżu Chyrowskiego. - Zeszyty Naukowe Uniwersytetu Jagiellońskiego, Prace Botaniczne 47: 1-383.

WoŁejko L. \& Bacieczko W. 2006. Szata roślinna rezerwatu „Stary Złom” koło Człopy. - Przegląd Przyrodniczy 3-4: 3-36.

WoŁKowYCKi D. \& PAWLIKOWski P. 2016. Zagrożone i chronione gatunki roślin naczyniowych w Puszczy Rominckiej (Polska północno-wschodnia). - Fragmenta Floristica et Geobotanica Polonica 23(1): $13-28$.

ZAJĄC A. \& ZAJĄC M. (red.). 2001. Atlas rozmieszczenia roślin naczyniowych w Polsce. s. xii + 714. Nakładem Pracowni Chorologii Komputerowej Instytutu Botaniki Uniwersytetu Jagiellońskiego, Kraków.

ZAJĄC M. \& ZAJĄC A. 2009. Elementy geograficzne rodzimej flory Polski. s. 94. Nakładem Pracowni Chorologii Komputerowej Instytutu Botaniki Uniwersytetu Jagiellońskiego, Kraków.

ZemaneK B. 1989. Rośliny naczyniowe Bieszczadów Niskich i Otrytu (polskie Karpaty Wschodnie). - Zeszyty Naukowe Uniwersytetu Jagiellońskiego, Prace Botaniczne 20: 1-185.

\section{SUMMARY}

Ophioglossum vulgatum (family Ophioglossaceae, class Psilotopsida) is a rare, protected species, listed in the red list of vascular plants. Three new localities of $O$. vulgatum were found in 2019 - two in the Low Beskids (Bednarka, Żydowskie) and the third in Klemensów in the Zamojska Valley (Fig. 2), growing in Molinio-Arrhenatheretea grassland. The populations contained 20-50 plants, most of which had developed sporophyl shoots (Fig. 1). Three previously recorded localities of adders tongue from the Low Beskids and two from the Zamojska Valley were not reconfirmed. In Poland, 707 stations have been found (Fig. 2). After 2000, 187 localities were recorded (Tab. 1).

Wptynęto: 09.04.2020 r.; przyjęto do druku: 30.12.2020 r. 